\title{
Factors that Shape and Determine the Social Studies Curriculum in Philippine Basic Education (1980s-2010)
}

\author{
Lorina Y. Calingasan \\ College of Education, University of the Philippines, Diliman, Quezon City, Philippines
}

\begin{abstract}
How to cite
Calingasan, L. Y. (2018). Factors that Shape and Determine the Social Studies Curriculum in Philippine Basic Education (1980s-2010). Asia Pacific Journal on Curriculum Studies, 1(1), 1-6. https://doi.org/ 10.53420/apjcs.2018.1
\end{abstract}

\begin{abstract}
This study analyzes the process of curriculum development in Social Studies in Philippine basic education from 1980 to 2010 and argues that the curriculum, as a product, is shaped and determined by political contexts and results from the deliberations and decisions of a group of people tasked to craft it. Analyzing primary documents such as memos, reports, curriculum documents, and teacher's guides, and drawing from interviews with curriculum writers and consultants, this study is able to identify socio-political factors that influence the articulation of curriculum objectives and content. Teachers, consultants, and staff from the Department of Education, who constitute the curriculum writing team play different roles and representations as the curriculum document is produced. In the process, they each wield levels of power in influencing the curriculum.
\end{abstract}

Keywords: Social Studies, curriculum development, basic education

\section{Introduction}

Curriculum development in Philippine basic education is by convention, the work of the government. It starts with the Department of Education's curriculum office (formerly Curriculum Development Division, now Bureau of Curriculum Development), and disseminated through a department order handed to the different geographical regions and divisions across the Philippines and down to the schools where teachers are expected to implement them in the classroom (Bago, 2001; Bernardo \& Mendoza, 2009; Mariñas \& Ditapat, 1998).

This paper intends to inquire how the Social Studies curriculum was developed from 1980 to 2010 and identify factors that influence its development.

\section{Origin, Definition, and Purpose of Social Studies}

This paper utilizes the history of the development of Social Studies curriculum in the US as its framework, and notes the interplay of context in identifying the goals and focus of Social Studies (see Table 1).

Most scholars trace the institution of Social Studies as a school subject in high school to a 1916 report by the US Committee on Social Studies tasked to review whether the social science courses taken by high school students were what college education required.

As recommended by the 1916 Committee, Social Studies, defined as "those whose subject matter relates directly to the organization and development of human society, and to man as a member of a social group" (Nelson, 1994, p. 20) was implemented as a subject in high school.

This new subject replaced civics education in high school and altered the way history was traditionally taught. Civics would be integrated with Geography and History at Grades 7 until 9. History at Grades 10 and 11 would be taught, not using its chronological organization but according to selected topics/problems deemed interesting to students or that would help explain the present. In Grade 12, Social Studies would culminate in Problems of Democracy, a subject on social problems viewed from the perspectives of political science, sociology, economics, and history. 
It was argued that Social Studies, as a subject, should develop among students "a sense of responsibility and the will to participate effectively in the promotion of the social well-being" (Nelson, 1994, p. 17). The need for civics education rested on the fact that at that time, there was an increasing number of immigrants from Europe coming to the United States who needed to be initiated to the ideals of democracy and were expected to respond to the demands of industrialization.

Table 1

Social Studies Curriculum in the US, 1920s-1980s

\begin{tabular}{llll}
\hline Year & Context & $\begin{array}{l}\text { Purpose of Social } \\
\text { Studies }\end{array}$ & Focus of Social Studies \\
\hline $1920 \mathrm{~s}$ & Social Efficiency & $\begin{array}{l}\text { Citizenship } \\
\text { Education } \\
\text { Social Transformation }\end{array}$ & $\begin{array}{l}\text { Civics } \\
\text { Social Problems } \\
\text { Social Problems } \\
\text { Expanding Environment } \\
\text { Curriculum }\end{array}$ \\
& Great Depression & $\begin{array}{l}\text { Current Events } \\
\text { Citizenship Education }\end{array}$ & $\begin{array}{l}\text { Core Curriculum } \\
\text { Patriotism }\end{array}$ \\
1940s & World War II & $\begin{array}{l}\text { Academic Excellence } \\
\text { Scientific Knowledge }\end{array}$ & $\begin{array}{l}\text { "New Social Studies" } \\
\text { Inquiry Method }\end{array}$ \\
$1950 \mathrm{~s} \&$ & $\begin{array}{l}\text { Cold War Sputnik } \\
\text { 1960s }\end{array}$ & Launch & $\begin{array}{l}\text { History } \\
\text { History Standards }\end{array}$ \\
$1980 \mathrm{~s}$ & $\begin{array}{l}\text { Assessment Reports } \\
\text { on the State of }\end{array}$ & Historical Literacy \\
& Education & & \\
\hline
\end{tabular}

Saxe (1991), however, refuted the popular belief that the 1916 document created the term Social Studies. He cited Heber Newton's 1887 book titled Social Studies about the social conditions and prospects of urban workers and Sarah Bolton's Social Studies in England published in 1883, which sought to utilize the social sciences to promote social welfare of urban Club" where members conduct investigations of social conditions and institutions to improve their local conditions, wrote the first outline of a "program for social study" (Saxe, 1991, p. 18) in 1897. Saxe (1992) also noted that Social Studies was made part of the school curriculum in 1897 by Edmund James, president of the American Academy of Political and Social Sciences. Using the natural sciences model of grouping the fields of geology, mineralogy, biology, etc. under the rubric 'nature studies' for use in public schools, James suggested pulling together the social sciences for use in the lower schools under the umbrella of 'social study.' Thus, as Saxe argued, Social Studies did not begin with nor extend from the traditional history as most would interpret the 1916 document, but from the social welfare activists who conceived social science as a general area of inquiry to help solve societal problems. He noted that this general or holistic approach to treating social issues and problems surfaced in education, first under the rubric "social education" and then, finally, as "social studies" (Nelson, 1994, p. 270).

Those who considered the 1916 document as primary in engendering Social Studies also noted that the goal of citizenship education was expounded in three strands: transmission, transformation, and progressivism. Addressing the specific needs of the times as a) preservation of democratic life, b) preparation of citizens for industrialized economy, and c) initiation of immigrants to the American way of life, it established the goal of producing good citizens by transmitting to students the knowledge, values, or culture needed in a democratic society. This aim of transmission would materialize in the Community Civics course where the student would know the meaning of community life "what it does for him and how it does it, what the community has to expect from him and how he may fulfill his obligation" (Nelson, 1994, p. 30).

Citizenship education also recognized the study of social problems as a necessary part of the education of citizens. As the 1916 document discussed this aim in the context of social efficiency specifically manifested in the "intelligence and the will to participate effectively in the promotion of social well-being" (Nelson, 1994, p. 17), such implied an element of social transformation. Thus, the aim of social studies to develop good citizens included the citizen taking action to solve a problem and transform his environment.

The third strand woven into this discourse was the fact that citizenship education started with the teaching principle on student needs and interest. There were numerous references to John Dewey's philosophy and the choice of content for study according to "the present life interests of the pupil, or those which he could use in his present processes of growth" (Nelson, 1994, p. 19) was adopted. It could also be implied that the ultimate goal of Social Studies education was to "meet the needs of the present growth." 
(Nelson, 1994, p.53). Fallace (2009) concluded that the 1916 committee report was Dewey-inspired and drew much from him and his progressive peers.

Since then Social Studies as a subject became part of the school curriculum. In the1920s, the goal of civics/citizenship training was pursued and social problems and controversial issues continued to be the focus of Social Studies. When the Great Depression happened in the 1930s, studying social problems and issues proved to be inadequate. The purpose of Social Studies then shifted from citizenship education to social reconstruction. Problems were studied not because they were the immediate concern of the individual student, but because Social Studies had to take part in creating social change. During World War II, citizenship education again became the central emphasis of Social Studies, but with a focused attention on patriotism and current events. Emphasis was on reflective process, studying problems meaningful to youth, and building the right attitudes rather than learning a specific content.

In the 1950s and 1960s, a study on the historical illiteracy of American school children and the launching of Sputnik by the Soviets called for a more rigorous academic study of the social sciences, moving away from the study of social problems. This came to be known as the "new Social Studies" (Nelson, 1994).

In 1983, the publication of A Nation at Risk led to a proposed curriculum pattern emphasizing historical studies and recommended that schools adopt more rigorous, measurable standards and heighten expectations for academic performance.

\section{Research Method}

This study analyzed the curriculum documents of Social Studies from 1982 -2010 (see Table 2). Key informant interviews were also conducted with master teachers, officials from the Department of Education's Bureau of Curriculum Development, and consultants who were directly involved in the development of the curricula.

Table 2

Curriculum Revisions in Elementary and Secondary Social Studies, 1982-2010 (based on curriculum titles)

\begin{tabular}{ll}
\hline Year & Curriculum titles \\
\hline 1982 & $\begin{array}{l}\text { New Elementary School Curriculum (NESC) Minimum Learning } \\
\text { Competencies }\end{array}$ \\
& $\begin{array}{l}\text { New Secondary Education Curriculum (NSEC) Desired Learning } \\
\text { Competencies }\end{array}$ \\
& $\begin{array}{l}\text { New Elementary School Curriculum (NESC) Philippine Elementary } \\
\text { Schools Learning Competencies }\end{array}$ \\
& New Secondary Education Curriculum (NSEC) Philippine Secondary \\
1997 & Schools Learning Competencies (PSSLC) \\
& Basic Education Curriculum (BEC) \\
2002 & 2010 Basic Education Curriculum (BEC) Philippine Elementary \\
& Learning Competencies, Philippine Secondary Learning Competencies \\
\hline
\end{tabular}

\section{Political Context, Educational Goals, and Textbooks}

Educational goals in the 1980s-2010 were crafted within specific political contexts and consequently, such contexts define how the goals were articulated. The goals of the 1982 New Elementary School Curriculum (NESC) were obtained from Batas Pambansa Blg. 232 (Education Act of 1982) issued during the time of President Ferdinand Marcos, while the goals of 1989 New Secondary Education Curriculum (NSEC) were based on the 1987 Constitution drafted during the time of President Corazon Aquino. The elementary and secondary Social Studies curricula therefore spanned within the contexts of two political eras, i.e., Marcos' dictatorship and Aquino's restoration of democracy. This change in the political set-up transformed the articulation of educational goals across the said periods. While the 1982 goals reiterated the goals of the previous 1970 elementary curriculum (The Revised Elementary Education Program, 1970), the 1989 goals (Implementation of the New Secondary, 1989) were not a reiteration of the 1973 secondary curriculum (Department of Education and Culture, 1976). Instead, the 1989 goals were revised to reflect the changes in the political scene. For instance, the goal to develop "a reasoned commitment to national development" in 1973 became "enlightened commitment to national ideals" (Nelson, 1994) in 1989, signifying a change in tone (from reason to enlightenment) and construct (from national development to national ideals). The acquisition of work skills had to be matched 
with work ethics in 1989, putting forward the need for values. Lastly, the arts and sciences, then seen as sources of pleasures and profit, were now viewed not only for self-fulfillment but also for promoting the welfare of others.

Table 3

Comparing the 1973 and 1989 Curriculum Objectives

\begin{tabular}{|c|c|}
\hline $\begin{array}{l}\text { Objectives of the } 1973 \text { Revised } \\
\text { Secondary Education Curriculum } \\
\text { (RSEC) }\end{array}$ & $\begin{array}{l}\text { Objective of the } 1989 \text { New Secondary } \\
\text { Education Curriculum (NSEC) }\end{array}$ \\
\hline $\begin{array}{l}\text { Develop a reasoned commitment to the } \\
\text { goals of national development by } \\
\text { cherishing, preserving, and } \\
\text { developing, moral and spiritual values } \\
\text { and other aspects of the national } \\
\text { heritage desirable in Philippine society } \\
\text { - Acquire the basic occupational skills, } \\
\text { knowledge, and information essential } \\
\text { for obtaining initial gainful } \\
\text { employment and for making intelligent } \\
\text { choice of occupation or career } \\
\text { - Understand the wide possibilities of } \\
\text { the arts and the sciences as permanent } \\
\text { sources of pleasures and profit, and } \\
\text { discover, broaden, and heighten his } \\
\text { abilities in and appreciation for them }\end{array}$ & $\begin{array}{l}\text { - Develop an enlightened commitment to } \\
\text { the national ideals by cherishing, } \\
\text { preserving and developing moral, } \\
\text { spiritual, and socio-cultural values as } \\
\text { well as other desirable aspects of the } \\
\text { Filipino heritage } \\
\text { - Acquire work skills, knowledge and } \\
\text { information, and a set of work ethics } \\
\text { essential for making intelligent choice } \\
\text { of an occupation or career and for } \\
\text { specialized training in specific } \\
\text { occupation }\end{array}$ \\
\hline
\end{tabular}

The 1989 NSEC was launched three years after Marcos was unseated from power through a non-violent revolution. As democracy was restored, then Department of Education Secretary Lourdes Quisumbing (1994) implemented the Values Education Programme to strengthen the moral fiber of the Filipino people, weakened by 14 years of dictatorship. NSEC used this values education framework to transform the goals of secondary education accordingly, as was discussed.

The production of instructional materials was also affected by these political changes. During the Marcos era, the Textbook Board, the body that selects and approves textbooks for elementary and secondary schools, was replaced by the Textbook Council, whose members were confined to the Minister of Education and Culture, the Directors of the Bureau of Elementary and Bureau of Secondary Education, and two presidential appointees (Creating the Textbook Council, 1982). In comparison, the Board of Textbooks created in 1947 was composed of presidential appointees who were not from the Department of Education (An Act Creating a Board, 1921).

Also, in 1982 the Instructional Materials Corporation (IMC) was created as the agency in charge of 1) production and distribution of textbooks and instructional materials for public schools, and 2) formulating policy recommendations and standards governing textbooks and instructional materials for adoption of the Textbook Council (Creating the Textbook Council, 1982). Given such power, IMC was able to monopolize the production of textbooks for all public schools and reduce the role of private publishers to mere reproduction of IMC-produced textbooks.

From 1996-2010, however, private publishers resumed production and distribution of textbooks. In 1991, The IMC was transformed from being a government-owned and controlled corporation to a regular government agency, now called the Instructional Materials Development Center (IMDC). In 1995, R.A. 8047 (Book Publishing Industry Development Act, 1995) was passed, and IMDC subsequently became part of the National Book Development Board (NBDB). DECS, in consultation with NBDB, prescribed the guidelines in evaluating, selecting, and approving textbook manuscripts and prototypes submitted by private publishers.

\section{The Role of the Curriculum Writing Team}

The curriculum writing team was composed of master teachers, staff from the Department of Education's Curriculum Development Division, and consultants (content experts) invited by the Department. This triune composition seemed to be the recurring arrangement whenever the curriculum is revised or developed. 
The Master Teacher (MT) rank qualified teachers to become curriculum writers. However, there seemed to be no established criteria or screening process as to who among the MTs could take part in writing the curriculum. The interview responses of the MTs who wrote the learning competencies were very interesting. When asked why they were recruited to write the curriculum, they enumerated the following reasons:

1. active participation in mass training for the implementation of the curriculum (MT2, personal communication, May 6, 2014);

2. recommendation from supervisor (MT3, personal communication, May 7, 2014);

3. writing skills demonstrated in a workshop organized by the Department of Education (MT1, personal communication, December 13, 2013).

The above reasons basically listed special qualifications as participant (ability to participate in discussions), writer (ability to write well), and teacher (with qualities worthy of a supervisor's recommendation). There was no mention of the necessity of curriculum development expertise.

The staff (S) from the Department of Education were supposed to be the curriculum experts in the team. Although, the Department's staff who were part of the writing committee were identified not as curriculum experts but as employees from the Curriculum Development Division, or more generally speaking, from the Bureau of Elementary Education or the Bureau of Secondary Education. Interviews with the four staff members revealed that all of them were former MTs in the public school system and to them, it was a "career move" to be able to transfer and be part of the central office of the Department (S1, personal communication, February 24, 2014; S2, personal communication, May 7, 2014; S3, personal communication, February 26, 2014; S4, personal communication, June 2, 2014).

Consultants (C) are subject area specialists from different universities (Bureau of Secondary Education, 1994.) They are supposed to play an active role in the writing process. However, consultants interviewed for this study were very certain that their tasks were limited to

1. editing the current curriculum by deleting learning competencies that were duplicated $(\mathrm{C} 1$, personal communication, November 15, 2013);

2. reacting to manuscripts the teachers and the Department of Education staff had produced (C2, personal communication, March 10, 2014);

3. checking if the competencies were acceptable (C3, personal communication, April 7, 2014).

In the 1970 s, the consultants were already present while the curriculum was being written. During this time, however, the consultants came in after the curriculum had been written and their comments were considered by the writing team as "coming from the outside" (Nelson, 1994). The consultants also perceived that their comments were ignored since they were not given the chance to check how the comments were integrated in the final draft of the curriculum.

This work dynamics between consultants and writers can be interpreted in terms of power relations. The superior role usually played by consultants as content experts and the tendency of teachers to subordinate their own ideas to the content experts, define a kind of hierarchy in terms of knowledge authority. On the other hand, as consultants were not part of the regular deliberations of the writing team, their recommendations were not taken as mandatory. Teacher-writers in this case reverse the power relations where they have the authority to either accept or reject them. In the case of the Social Studies curriculum for this period, they ignored the comments of the consultants.

\section{Summary}

1. The development of the Social Studies curriculum from 1980 until 2010 was influenced by the following factors: While the elementary curriculum was conceptualized during the Marcos period and the secondary curriculum, during the Aquino administration, the two different political contexts affected the way the educational goals were expressed.

2. The production of textbooks was also affected by these two different political contexts. From 1982 to 1995, the government through the IMC, monopolized the production and distribution of textbooks for public schools. From 1996 to 2010 , private publishers resumed production and distribution of textbooks, with the creation of the NBDB.

3. The curriculum writing team was composed of master teachers, the Department of Education staff, and consultants (content experts). Given the diminished role of consultants in influencing the curriculum, with their comments ignored or not integrated in the final draft, it can be said that the curriculum from 1980 until 2010 was significantly the handiwork of the master teachers and the DE staff. 


\section{References}

An Act Creating a Board to have Charge of Selection and Approval of the Textbooks to be Used by the Colleges and Schools of the Government and For Other Purposes, Act 2957 (1921).

Bago, A. L. (2001). Curriculum development: The Philippine experience. Manila: De La Salle University Press.

Bernardo, A. B., \& Mendoza R. J. (2009). Makabayan in the Philippine basic education curriculum: Problems and prospects for reforming student learning in the Philippines. In C. H. Ng \& P. D. Renshaw (Eds.), Reforming learning (pp. 181-197). London: Springer Science. Retrieved from https:// link.springer.com/chapter/10.1007\%2F978-1-4020-3024-6_9

Book Publishing Industry Development Act, R.A. 8047 (1995).

Bureau of Secondary Education Curriculum Development Division. (1994). Curriculum reform: Towards relevant secondary education.

Creating the Textbook Council and the Instructional Materials Corporation, Defining Their Powers and Functions and for Other Purposes, E.O. 806 (1982).

Department of Education and Culture. (1976). Isang patnubay sa pagtuturo ng Araling Panlipunan I (Batayan). Manila: DEC Social Studies Center. Education Act of 1982, B.P. 232 (1982).

Fallace, T. (2009). John Dewey's influence on the origins of Social Studies: An analysis of the historiography and new interpretation. Review of Educational Research, 79(2), 601-624. doi: 10.3102/0034654308326159

Implementation of the New Secondary Education Curriculum under the 1989 Secondary Education Development Program, Department of Education, Culture and Sports Order No. 11 (1989).

Mariñas, B. O. \& Ditapat, M. P. (1998). Philippines: Curriculum development. UNESCO statistical yearbook [PDF file]. Paris: UNESCO. Retrieved from www.ibe.unesco.org/curriculum/Asia\%20Networkpdf/ ndrepph.pdf

Nelson, M. R. (1994). The social studies in secondary education: A reprint of the seminal 1916 report with annotations and commentaries. Bloomington, Indiana: ERIC Clearinghouse for Social Studies/Social Science. Retrieved from ERIC database. (ED374072)

Quisumbing, L. (1994). A study of the Philippine values education programme (1986-1983). Paper presented at 44th International Conference on Education, Geneva. Retrieved from http://unesdoc.unesco.org/images/0009/000997/099770eb.pdf

The Revised Elementary Education Program, Department of Education and Culture Order No. 10 (1970).

Saxe, D. W. (1991). Social studies in schools: a history of the early years. New York: State University of New York Press.

Saxe D. W. (1992). Framing a theory for social studies foundations. Review of Educational Research. 62(3), 259-277. Retrieved from http://www.jstor.org/stable/1170739 